Anais da Academia Brasileira de Ciências (2006) 78(3): 573-589

(Annals of the Brazilian Academy of Sciences)

ISSN 0001-3765

www.scielo.br/aabc

\title{
The evolution of Neoproterozoic magmatism in Southernmost Brazil: shoshonitic, high-K tholeiitic and silica-saturated, sodic alkaline volcanism in post-collisional basins
}

\author{
CARLOS A. SOMMER ${ }^{1}$, EVANDRO F. LIMA ${ }^{1}$, LAURO V. S. NARDI ${ }^{1}$, \\ JOAQUIM D. LIZ ${ }^{2}$ and BRENO L. WAICHEL ${ }^{3}$ \\ ${ }^{1}$ Centro de Pesquisas em Geoquímica (CPGq), Instituto de Geociências \\ Universidade Federal do Rio Grande do Sul (UFRGS), Av. Bento Gonçalves, 9500, Cx. Postal 15001 \\ 91501-970 Porto Alegre, RS, Brasil \\ ${ }^{2}$ Programa de Pós-graduação em Geociências (PPGEO) \\ Universidade Federal do Rio Grande do Sul (UFRGS), Av. Bento Gonçalves, 9500, Cx. Postal 15001 \\ 91501-970 Porto Alegre, RS, Brasil \\ ${ }^{3}$ Universidade Estadual do Oeste do Paraná (UNIOESTE), Cx. Postal 000701, 85814-110 Cascavel, PR, Brasil \\ Manuscript received on June 8, 2005; accepted for publication on February 2, 2006; \\ contributed by LAURO V.S. NARDI*
}

\begin{abstract}
The Neoproterozoic shoshonitic and mildly alkaline bimodal volcanism of Southernmost Brazil is represented by rock assemblages associated to sedimentary successions, deposited in strike-slip basins formed at the post-collisional stages of the Brasilian/Pan-African orogenic cycle. The best-preserved volcanosedimentary associations occur in the Camaquã and Campo Alegre Basins, respectively in the Sul-riograndense and Catarinense Shields and are outside the main shear belts or overlying the unaffected basement areas. These basins are characterized by alternation of volcanic cycles and siliciclastic sedimentation developed dominantly on a continental setting under subaerial conditions. This volcanism and the coeval plutonism evolved from high-K tholeiitic and calc-alkaline to shoshonitic and ended with a silica-saturated sodic alkaline magmatism, and its evolution were developed during at least $60 \mathrm{Ma}$. The compositional variation and evolution of post-collisional magmatism in southern Brazil are interpreted as the result mainly of melting of a heterogeneous mantle source, which includes garnet-phlogopite-bearing peridotites, veined-peridotites with abundant hydrated phases, such as amphibole, apatite and phlogopite, and eventually with the addition of an asthenospheric component. The subduction-related metasomatic character of post-collisional magmatism mantle sources in southern Brazil is put in evidence by Nb-negative anomalies and isotope features typical of EM1 sources.
\end{abstract}

Key words: post-collisional, Neoproterozoic, volcanism, shoshonite, Na-alkaline.

\section{INTRODUCTION}

The Neoproterozoic in southernmost Brazil is characterized mainly by plutonism along large trans-

\footnotetext{
*Member Academia Brasileira de Ciências

Correspondence to: Carlos Augusto Sommer

E-mail: casommer@sinos.net
}

lithospheric shear belts and plutonism, volcanism and sedimentation in strike-slip basins, namely the Camaquã, Campo Alegre, Castro and Itajaí basins. These volcano-sedimentary associations are situated away from the main shear zones, lying on basements of Brasiliano age (Castro and Itajaí Basins), 
Paleoproterozoic granulitic rocks of the Luiz Alves Craton (Campo Alegre Basin) and diverse older igneous and metamorphic terrains (Camaquã Basin) (Fig. 1). These basins are related to the post-collisional stages of the Brasiliano-Pan-African cycle and are considered as strike-slip basins, although there are controversies on their classifications and mechanisms of generation (Almeida et al. 1981, Brito Neves and Cordani 1991, Chemale Jr. 2000, Gresse et al. 1996, Paim et al. 2000). The concept of post-collisional setting assumed in this paper is taken from Liégeois (1998) and Bonin (2004), as the complex period which postdates the main collision and can include large movements along transcurrent shear belts, oblique collision, lithosphere delamination, rifting, subduction of small tectonic oceanic plates, and strike-slip basin volcanism and sedimentation.

Important volcanic cycles have been identified mainly in the Camaquã and Campo Alegre Basins. In the former three distinct cycles have been identified (Wildner et al. 2002): (i) the older volcanic rocks show shoshonitic affinity (Bom Jardim Group, Hilario Formation), are dominantly of intermediate composition, with some basic and acidic occurrences; (ii) shoshonitic rocks are succeeded by a bimodal sodic mildly alkaline volcanism (Cerro do Bugio Group, Acampamento Velho Formation), represented mainly by acidic effusive/ explosive episodes and a minor basic pole; (iii) the youngest volcanic rocks (Guaritas Group, Rodeio Velho Member) are characterized by basic to intermediate lava-flow deposits of sodic mildly alkaline to high-K tholeiitic (Fig. 1a). In the Campo Alegre Basin the volcanic sequence is bimodal, sodic, alkaline and silica saturated, similar to that observed in the Camaquã Basin (Fig. 1b).

Petrographic, geochemical and geochronological data of Neoproterozoic volcanism in some of the post-collisional basins of southernmost Brazil are reviewed and discussed in this paper, in order to re-evaluate the evolution of post-collisional magmatism and its probable sources.

\section{THE CAMAQUÃ AND CAMPO ALEGRE BASINS}

The Camaquã Basin shows an evolution characterized by the alternation of depositional intervals, with accumulation of thick sedimentary and volcano sedimentary sequences and dominantly erosive intervals. During the filling phase volcanic deposits were formed, alternated with siliciclastic sedimentation. The sedimentary sequence of the Camaquã Basin represents an evolution from shallow marine to lacustrine-alluvial and desertic settings in a typical continental environment (Paim et al. 2000). Important volcanic cycles were developed in this basin (Fig. 1a). Intermediate effusive deposits, associated to volcaniclastic sequences and hypabissal bodies, constitute the Hilario Formation, which presents shoshonitic affinity, and most of it is included in the Lavras do Sul Shoshonitic Association (Lima and Nardi 1998). It is succeeded by a bimodal volcanism - Acampamento Velho Formation - of silica-saturated-sodic-alkaline affinity, dominated by an expressive acidic magmatism and represented mainly by effusive and pyroclastic flow deposits (Sommer et al. 2005, Wildner et al. 2002, Almeida et al. 2002). The youngest unit - Rodeio Velho Member - is constituted mainly by intermediate to basic lava flows, with transitional or tholeiitic affinity (Almeida et al. 1997).

The Campo Alegre Basin situated in the northeast portion of the Santa Catarina State (Fig. 1b), presents a non-deformed and non-metamorphosed volcano-sedimentary sequence and a large amount of granitic intrusions. It lies on Archean granulite terrains and its formation is probably related to crustal relaxation due to lithospheric thickening that occurred during the Brasiliano cycle (Basei et al. 1992). The basin alternates deposition and erosive episodes in a shallow marine setting, where the sedimentary sequences were deposited and a subaerial continental setting characterized mainly by volcanic deposits. The volcanism in this basin is represented only by one volcanic cycle, the Campo Alegre Formation (Ebert 1971, Daitx and Carvalho 1980), situated in the intermediate portion of the 


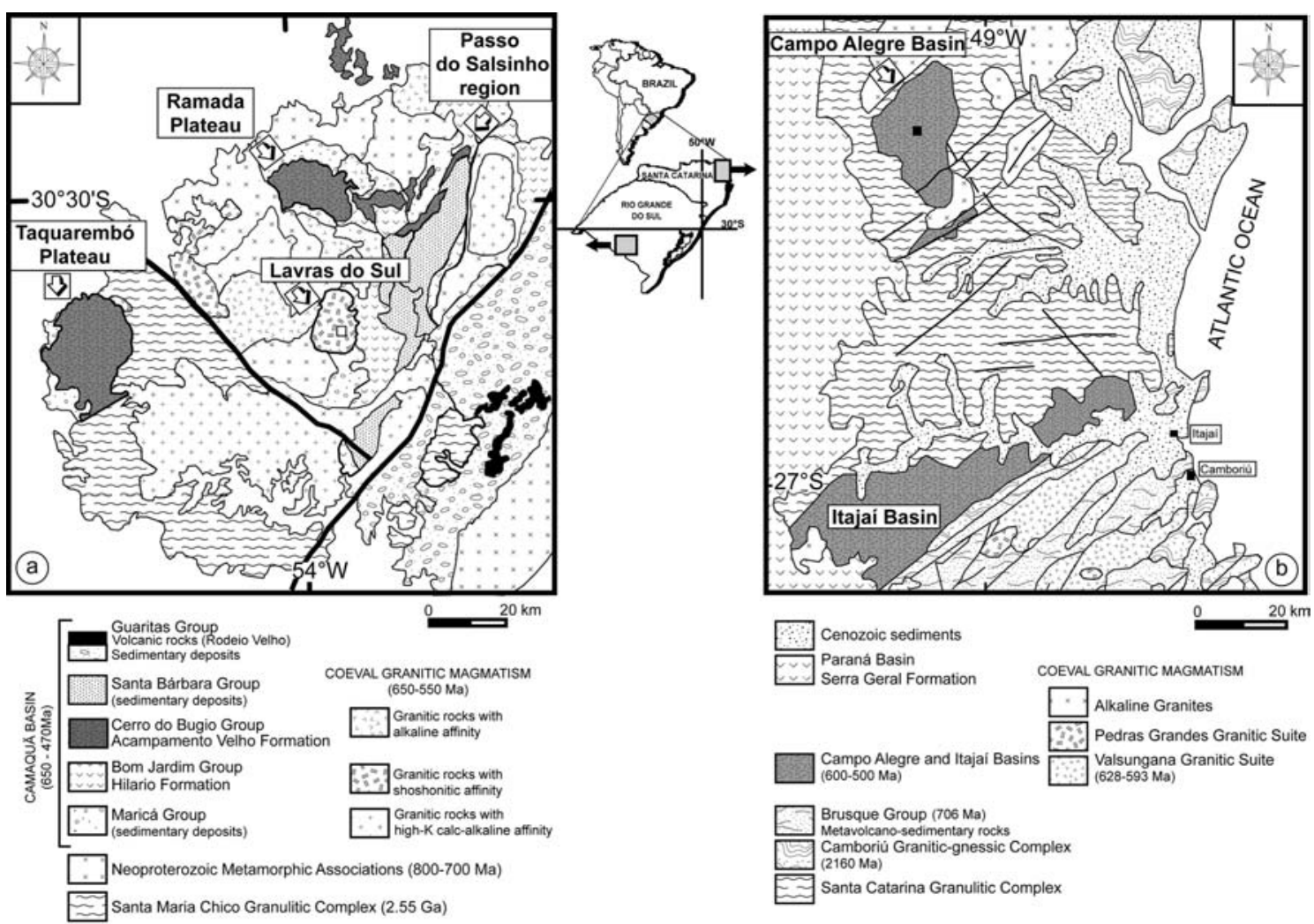

Fig. 1 - Localization and simplified geological maps of the Camaquã (a) and Campo Alegre (b) basins (modified from Wildner et al. 2002).

basin, and constituted by a bimodal volcanic sequence (Waichel et al. 2000).

\section{THE SHOSHONITIC VOLCANISM}

The shoshonitic rocks represent the oldest magmatic unit in the Camaquã Basin, and includes volcanic and plutonic rocks, which are intercalated with volcanogenic conglomerates and sandy to muddy deposits related to turbidity flows, that are predominant in the top levels of this stratigraphic unit.

The effusive rocks are represented mostly by potassic trachybasalts and trachyandesites (shoshonites) spatially and temporally associated with monzonitic to quartz-monzonitic and lamprophyric hypabissal rocks, epizonal granitoids and cummulatic leucodiorites (Lima and Nardi 1998).
Basic volcanic rocks are mostly in the lower stratigraphic levels, as lava flows or small shallow intrusions. They are porphyritic olivine (Fo66-68) basalts with augite $\left(\mathrm{Wo}_{39-43} ; \mathrm{En}_{44-49} ; \mathrm{Fs}_{9-15}\right)$, labradorite to andesine, and ilmenite, in a matrix made of andesine to oligoclase, apatite and modified glass. Intermediate rocks are largely dominant in the volcanic sequence. They show porphyrytic and glomeroporphyrytic textures, abundant floworiented labradorite-andesine phenocrysts, and minor amounts of augite ( $\mathrm{Wo}_{38}-43$ En 40-49 Fs 8-20), olivine $\left(\mathrm{Fo}_{62}\right)$, Ti-magnetite and apatite, and a matrix constituted by andesine-oligoclase crystallites and microlites along with glass.

Subordinated subarerial pyroclastic fall and flow deposits are characterized as lapilli lithic to crystal tuffs and crystal rich ignimbrites, with pla- 
gioclase, K-feldspar and quartz, involved by ash matrix. Volcaniclastic breccias are common and occur predominantly intercalated with trachyandesitic flows and fall tuffs.

Subvolcanic rocks are monzonites and quartz monzonites and occur as small intrusions around the Lavras Granite Complex. These rocks occur in two different facies: a porphyritic one with phenocrysts of plagioclase (oligoclase-andesine), Kfeldspar and amphibole (magnesium-hornblende), joined by biotite in more acidic members, and Ti-magnetite involved by a feldspar-rich groundmass, and an equigranular facies represented by medium-grained rocks with a similar mineralogy. These shallow intrusions are related to the latest magmatic stages of the shoshonitic magmatism. Cumulative leucodiorites occur as metric lenticular bodies involving the monzonitic rocks. They show equigranular texture, with strong flow orientation of plagioclase laths, besides clinopyroxene, magnetite and apatite as cumulus crystals, and small amounts of intercumulus material, mostly actinolite and chlorite.

Lamprophyre dikes and a lava-dome of shoshonitic affinity cut the volcanic sequence. Dykes are subvertical and generally 1 to $5 \mathrm{~m}$ wide, with typical panidiomorphic and porphyrytic textures characterized by abundant amphibole phenocrysts sometimes associated with clinopyroxene, engulfed by a feldspathic groundmass constituted mainly by plagioclase. Based mainly on mineralogical and textural evidence Lima and Nardi (1991) classified them as spessartitic. Clinopyroxene compositions vary from diopside to augite, and amphibole compositions vary from magnesiohastingsite to magnesiohornblende. Plagioclase composition ranges from andesine to albite, with high $\mathrm{Sr}$ contents $(2,000$ $3,000 \mathrm{ppm}$ ).

Plutonic rocks include quartz monzodiorites, quartz monzonites, monzogranites, granodiorites and syenogranites, with diopside ( $\mathrm{Wo}_{43} \mathrm{En}_{40} \mathrm{Fs}_{16}$ ), augite $\left(\mathrm{Wo}_{26} \mathrm{En}_{50} \mathrm{Fs}_{24}\right)$ and magnesium hornblende in the less differentiated rocks evolving to ferroedenite and biotite in the acidic terms. Apatite, zir- con, allanite, titanite, magnetite and ilmenite are the most frequent accessory phases. Hydrothermal activity is registered by secondary minerals, mainly chlorite, epidote, sericite, and calcite, and gold-copper-sulphide mineralization.

\section{The NA-ALKALINE Bimodal VolCANISM}

The bimodal volcanism represents the extrusive portion of the voluminous sodic, silica-saturated, alkaline, granitic magmatism, mostly metaluminous with minor peralkaline components (Nardi and Bonin 1991). The volcanism occurred under subaerial conditions and is exposed mainly in volcanic plateaus and ridges composed mostly of acidic lavas and pyroclastic deposits with minor intermediate and basic components (Sommer et al. 2005, Wildner et al. 2002, Almeida et al. 2002). Eruptive periods were generally initiated with explosive episodes and closed by effusive events, which suggests a decrease in volatile activity through the progress of volcanic eruption, representing a complete volcanic cycle.

Pyroclastic flows are the main volcaniclastic deposits and are represented by ignimbrites of comenditic affinity. The proximal and basal facies are characterized by co-ignimbritic breccias, constituted dominantly by juvenile, cognate and accidental blocks and lapilli in a tuffaceous matrix. This facies shows lateral gradational changes to ignimbrites with abundant lithoclasts and pumice lapillis, besides K-feldspar and quartz phenoclasts, separated in two main lithofacies: lenticulites and crystal-rich deposits, both presenting K-feldspar and quartz phenoclasts, pumice fragments and scarce lithoclasts with lapilli-size, in an abundant vitroclastic tuffaceous matrix. The pyroclastic flow deposits show evidences of hot, gas-supported emplacement, such as welding, high-temperature devitrification processes (spherulites, axiolites), lithophysae, perlitic fractures, gas-escape structures and vapor-phase crystals, which suggest the deposition from primary pyroclastic flows, generally restricted to subaerial settings.

Basic-intermediate rocks are represented by 
dykes and lavas of hawaiitic and mugearitic composition. Dykes show a fine-grained phaneritic texture with plagioclase, clinopyroxene, ilmenite and relicts of olivine, and lavas are porphyritic to glomeroporphyritic with plagioclase and pyroxene fenocrysts in a matrix constituted by plagioclase and pyroxene crystallites and microlites, and glass. Labradorite $\left(\mathrm{An}_{44-67}\right)$ is the commonest composition of plagioclase and clinopyroxene is augite (Wo39-43, $\left.\mathrm{En}_{38-48}, \mathrm{Fs}_{12-20}\right)$ in the dykes and diopside $\left(\mathrm{Wo}_{48-49}, \mathrm{En}_{28-37}, \mathrm{Fs}_{14-23}\right)$ in the lava flows.

Acidic lava flows and syn-volcanic intrusions are represented mainly by comenditic rhyolites and minor trachytes erupted through fracture zones, where they exhibit a sub-vertical flow foliation, gradating laterally to auto-breccias, lavas with sub-horizontal flow foliation and massive bodies. Acidic rocks consist of alkali feldspar, usually microperthite, quartz, zircon, and iron oxides as accessory phases. They generally show porphyritic to glomeroporphyritic textures, with low percentages of phenocrysts set in a matrix constituted of a mosaic of quartz and feldspar microlites and crystallites. Mafic phases are scarce and occur as aciculate crystals of amphibole and as rare pyroxene relicts partially replaced by amphibole and chlorite. Amphibole in the acidic rocks presents the compositions of sodic-calcic phase - ferro-winchite, ferrobarroisite and ferro-richterite, and a calcic one ferro-actinolite, which are frequently found in comenditic rocks (Strong and Taylor 1984). The microperthitic alkalli feldspar has the composition Or $_{84-98}$. However there are scarce homogeneous grains with a composition close to sanidine ( $\left.\mathrm{Or}_{41-47}\right)$. Plagioclase has been transformed to albite $\left(\mathrm{An}_{0,5-3}\right)$. Microphenocrysts of Ti-magnetite and ilmenite have compositions similar to those described on peralkaline rhyolites (Sutherland 1975).

\section{GEOCHEMICAL CHARACTERIZATION}

\section{The Shoshonitic Magmatism}

Basic-intermediate volcanic rocks plot in the trachybasalt and basaltic trachyandesite fields of the
TAS diagram (Fig. 2a) and their potassic character is indicated by $\mathrm{K}_{2} \mathrm{O}$ values greater than $\mathrm{Na}_{2} \mathrm{O}-2$ (Table I), which classify them as potassic trachybasalts and shoshonites (Le Maitre 2002). They are generally silica saturated with normative olivine, hypersthene and diopside. According to Lima and Nardi (1998) the Ni, Cr and Co contents in trachybasalts from LSSA are lower than those typical of primary magmas.

In the sliding normalization diagram proposed by Liégeois et al. (1998), the rock association plot in the shoshonitic field, characterized by high SNY (=mean [Rb-U-Th-Ta]NYTS) values and low SNX (=mean [Zr-Ce-Sm-Y-Yb]NYTS) values (Fig 2b).

Incompatible minor and trace elements show very enriched LILE and LREE ocean island basalts (OIB) normalized patterns (Fig. 3a), which are characteristic of shoshonitic rocks. $\mathrm{Nb}$ is depleted relative to LREE, which is considered as typical of magmas produced from sources modified by a previous subduction-related metasomatism (e.g. Kelemen et al. 1993). Their low $\mathrm{Nb} / \mathrm{La}$ and $\mathrm{La} / \mathrm{Ba}$ ratios are comparable to those reported for orogenic andesites by Davies and Hawkesworth (1994). HFS element contents are higher than in oceanic shoshonites, and similar to those reported by Pearce (1983) for those from continental margin. $\mathrm{Y}$ and $\mathrm{Yb}$ show lower contents than OIB (Fig. 3a), which may be ascribed to the presence of garnet in the residuum of this magmatism or to equilibration of ascendingslab melts with garnet peridotites as suggested by Kelemen et al. (1993). Ce/Sm and Sm/Yb ratios, as suggested by Davies and Hawkesworth (1994), also point out to the presence of garnet as a residual phase in the source of this magmatism. Chondrite normalized REE patterns (Fig. 3b) are characterized by $\mathrm{Ce}_{\mathrm{N}}$ values close to $100, \mathrm{Yb}_{\mathrm{N}}$ about 4 and absence of Eu anomalies; such features are also indicative of shoshonitic or high-potassium calc-alkaline magmas (Nardi and Lima 2000).

Intermediate and acidic terms keep the same patterns of incompatible elements relative to OIB (Fig. 3a). The regularity of REE patterns (Fig. 3b) observed for basic, intermediate and acidic rocks 

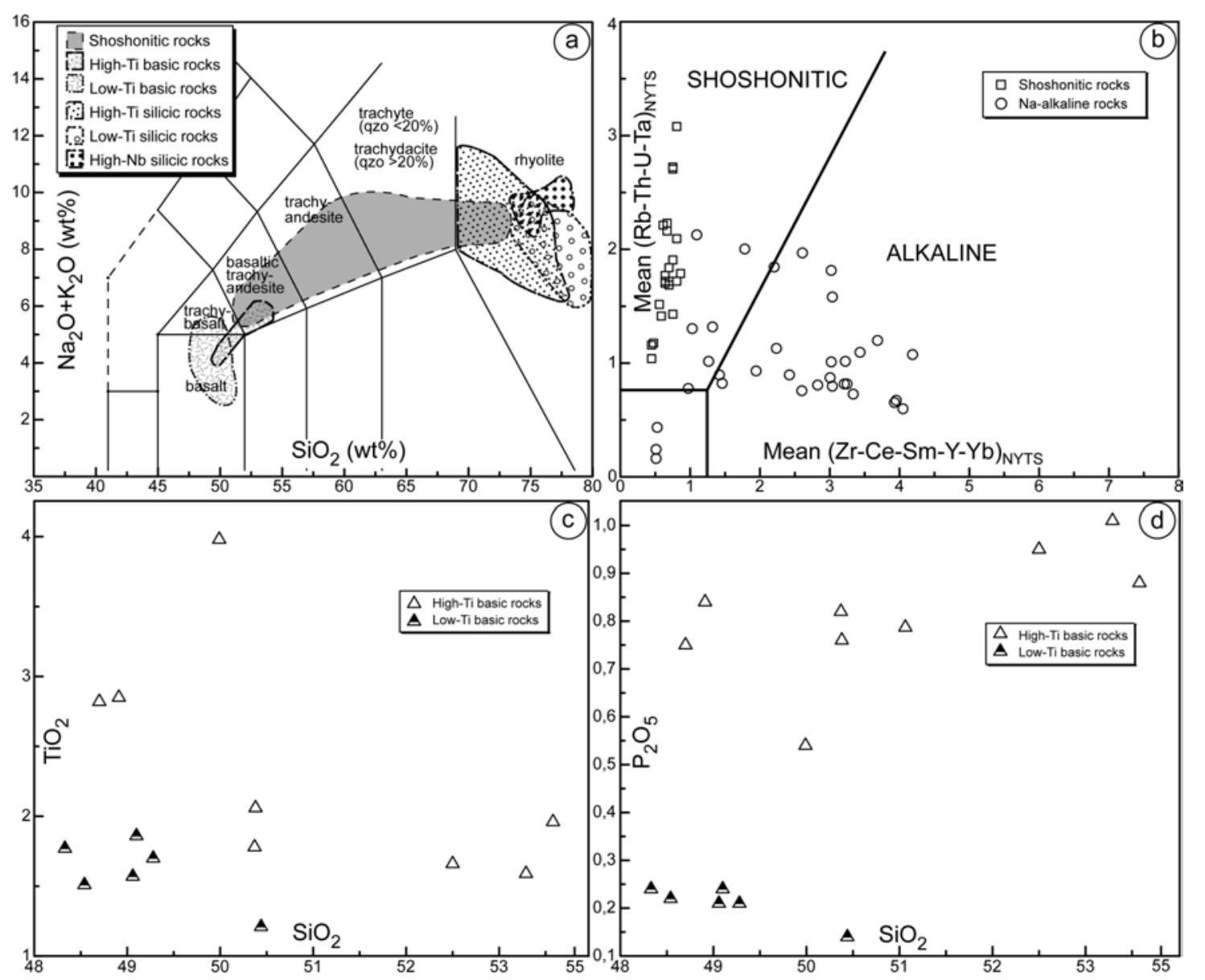

Fig. 2 - (a) TAS (Le Bas et al. 1986) diagram plotting for shoshonitic and Na-alkaline rock samples; (b) Sliding normalization diagram for shoshonitic and Na-alkaline rock samples (from Liégeois et al. 1998): circles: shoshonitic association; squares: Na-alkaline bimodal association; (c) $\mathrm{SiO}_{2}$ vs. $\mathrm{TiO}_{2}$ and (d) $\mathrm{SiO}_{2}$ vs. $\mathrm{P}_{2} \mathrm{O}_{5}$ diagrams for Na-alkaline basic rocks.

suggests their cogeneticity and consequently the origin of acidic rocks through the differentiation of basic and intermediate magmas.

Because several authors ascribe a significant role to lower crust as the source or a significant contaminant to shoshonitic magmas, the LSSA rocks were compared to the lower crust averages calculated by Wedepohl (1995), in order to evaluate its petrogenetic involvement. The basic and intermediate terms show enriched patterns for most elements, particularly for $\mathrm{Ba}, \mathrm{Sr}$ and LREE, while $\mathrm{Y}$ and $\mathrm{Yb}$ are depleted relative to lower crustal values. It seems thus, that lower crust is not compositionally suit- able as a source for shoshonitic magmas or even as a contaminant capable of explaining the increase of LILE or HFS element contents. Since plagioclase is usually an abundant residual phase during crustal melting, high $\mathrm{Sr}$ magmas are not expected, particularly if low-melt fractions are presumed. Granitic rocks maintain approximately the same geochemical trends, with $\mathrm{Sr}$ contents too high to be produced by crustal melting, whereas the enriched patterns for incompatible LILE would be an evidence of small melt fractions.

Granitic and rhyolitic rocks are metaluminous, with typically high $\mathrm{Ba}$ and $\mathrm{Sr}$ contents and mod- 
TABLE I

Chemical analyses for major (wt.\%) and trace (ppm) elements for representative whole-rock samples from southernmost Brazil post-collisional volcanic sequences.

\begin{tabular}{|c|c|c|c|c|c|c|c|c|c|}
\hline \multirow{2}{*}{ Sample } & A106 & A181 & B210 & B07 & LP225 & M11 & M35E & G16 & G14A \\
\hline & $\mathrm{SH}$ & $\mathrm{SH}$ & $\mathrm{SH}$ & $\mathrm{SH}$ & $\mathrm{SH}$ & $\mathrm{SH}$ & $\mathrm{SH}$ & $\mathrm{SH}$ & $\mathrm{SH}$ \\
\hline $\mathrm{SiO}_{2}$ & 53.60 & 54.90 & 51.26 & 52.00 & 61.00 & 62.46 & 66.18 & 70.19 & 70.35 \\
\hline $\mathrm{TiO}_{2}$ & 0.90 & 0.90 & 0.89 & 1.00 & 0.66 & 0.92 & 0.31 & 0.24 & 0.31 \\
\hline $\mathrm{Al}_{2} \mathrm{O}_{3}$ & 18.60 & 17.90 & 14.20 & 14.25 & 16.67 & 15.88 & 16.00 & 15.74 & 14.90 \\
\hline $\mathrm{Fe}_{2} \mathrm{O}_{3}$ & 7.55 & 6.53 & 7.50 & 9.31 & 6.25 & 5.98 & 2.79 & 2.34 & 2.67 \\
\hline $\mathrm{MnO}$ & 0.07 & 0.17 & 0.16 & 0.10 & 0.09 & 0.11 & 0.04 & 0.04 & 0.04 \\
\hline $\mathrm{MgO}$ & 3.20 & 2.80 & 9.17 & 8.20 & 2.23 & 1.20 & 0.98 & 0.58 & 0.64 \\
\hline $\mathrm{CaO}$ & 6.50 & 7.10 & 7.19 & 7.00 & 2.76 & 3.10 & 2.29 & 1.73 & 1.63 \\
\hline $\mathrm{Na}_{2} \mathrm{O}$ & 4.20 & 4.00 & 3.73 & 3.70 & 5.00 & 4.34 & 5.24 & 4.66 & 4.42 \\
\hline $\mathrm{K}_{2} \mathrm{O}$ & 2.90 & 2.20 & 1.92 & 2.00 & 4.27 & 4.34 & 3.67 & 3.62 & 3.95 \\
\hline $\mathrm{P}_{2} \mathrm{O}_{5}$ & 0.36 & 0.35 & 0.25 & 0.20 & 0.31 & 0.34 & 0.14 & 0.12 & 0.20 \\
\hline LOI & 2.30 & 2.70 & 3.00 & 2.00 & 1.57 & 1.24 & 1.06 & 0.53 & 0.86 \\
\hline Total & 100.2 & 99.5 & 99.27 & 99.76 & 100.81 & 99.89 & 98.69 & 99.8 & 99.97 \\
\hline $\mathrm{Ba}$ & 1300 & 1576 & 1085 & 1085 & 1890 & 2168 & 2119 & 1100 & 1181 \\
\hline $\mathrm{Rb}$ & 51 & 42 & 60 & 60 & 99 & 107 & 101 & 142 & 178 \\
\hline $\mathrm{Sr}$ & 1270 & 1166 & 740 & 710 & 895 & 656 & 1441 & 818 & 748 \\
\hline $\mathrm{Nb}$ & 22 & 21 & 16 & 14 & - & 14 & 15 & 10 & 14 \\
\hline $\mathrm{Zr}$ & 287 & 280 & 190 & 280 & 226 & 267 & 129 & 141 & 192 \\
\hline $\mathrm{Y}$ & 20 & 25 & 15 & 25 & - & 24 & 7 & 14 & 23 \\
\hline $\mathrm{La}$ & 51.12 & 53.23 & 45.42 & 52.03 & 25.75 & 59.4 & 42.4 & 34.7 & 47.2 \\
\hline $\mathrm{Ce}$ & 94.02 & 94.73 & 88.07 & 91.05 & 59.87 & 117 & 75.8 & 57.7 & 73.4 \\
\hline $\operatorname{Pr}$ & - & - & - & - & - & 13.4 & 7.38 & 5.85 & 7.56 \\
\hline $\mathrm{Nd}$ & 4.41 & 43.1 & 37.32 & 40.81 & 27.56 & 49.2 & 26.6 & 24.8 & 32 \\
\hline $\mathrm{Sm}$ & 6.85 & 10.53 & 6.67 & 7.2 & 4.83 & 9.3 & 4.3 & 4.32 & 5.58 \\
\hline $\mathrm{Eu}$ & 1.82 & 2.21 & 1.78 & 1.94 & 1.22 & 2.17 & 1.24 & 0.75 & 0.92 \\
\hline $\mathrm{Gd}$ & 4.95 & 6.11 & 4.79 & 5 & 3.78 & 7.2 & 2.7 & 3.12 & 4.08 \\
\hline $\mathrm{Tb}$ & - & - & - & - & - & 1.0 & 0.3 & - & - \\
\hline Dy & 2.83 & 3.91 & 2.73 & 2.78 & 2.77 & 4.4 & 1.5 & 2.35 & 3.35 \\
\hline Ho & 0.54 & 0.68 & 0.34 & 0.35 & 0.55 & 0.8 & 0.2 & 0.57 & 0.74 \\
\hline $\mathrm{Er}$ & 1.58 & 2.11 & 1.06 & 1.03 & 1.48 & 2.3 & 0.7 & 1.46 & 1.82 \\
\hline $\mathrm{Tm}$ & - & - & - & - & - & 0.33 & 0.10 & - & - \\
\hline $\mathrm{Yb}$ & 1.45 & 1.69 & 1.02 & 0.89 & 1.25 & 2.1 & 0.7 & 0.93 & 0.73 \\
\hline $\mathrm{Lu}$ & 0.2 & 0.28 & 0.14 & 0.12 & 0.17 & 0.31 & 0.09 & 0.17 & 0.12 \\
\hline $\mathrm{U}$ & - & - & - & - & - & 6.5 & 5.5 & - & - \\
\hline $\mathrm{Th}$ & - & - & - & - & - & 16 & 12.9 & - & - \\
\hline Hf & - & - & - & - & - & 7.3 & 4.7 & - & - \\
\hline $\mathrm{Ta}$ & - & - & - & - & - & 1 & 0.4 & - & - \\
\hline
\end{tabular}


TABLE I (continuation)

\begin{tabular}{|c|c|c|c|c|c|c|c|c|c|c|}
\hline \multirow{2}{*}{ Sample } & $\mathrm{R} 15$ & R27 & R57 & $\mathrm{R} 80$ & R183 & R14 & R78 & 4051 & R45 & R09 \\
\hline & A1 & A1 & A2 & A2 & A3 & A3 & A4 & A4 & A5 & A5 \\
\hline $\mathrm{SiO}_{2}$ & 47.29 & 47.73 & 46.26 & 51.70 & 73.82 & 73.12 & 74.91 & 79.63 & 72.13 & 77.26 \\
\hline $\mathrm{TiO}_{2}$ & 1.73 & 1.81 & 2.69 & 1.55 & 0.23 & 0.27 & 0.12 & 0.09 & 0.11 & 0.03 \\
\hline $\mathrm{Al}_{2} \mathrm{O}_{3}$ & 17.17 & 17.84 & 15.59 & 14.84 & 12.58 & 11.83 & 12.08 & 10.64 & 12.90 & 11.40 \\
\hline $\mathrm{Fe}_{2} \mathrm{O}_{3}$ & 13.86 & 11.18 & 11.42 & 10.94 & 3.06 & 3.38 & 1.93 & 1.86 & 2.41 & 1.01 \\
\hline $\mathrm{MnO}$ & 0.24 & 0.28 & 0.19 & 0.17 & 0.02 & 0.08 & 0.03 & 0.02 & 0.01 & 0.01 \\
\hline $\mathrm{MgO}$ & 4.02 & 4.52 & 4.36 & 5.69 & 0.25 & 0.25 & 0.09 & 0.03 & 0.12 & 0.04 \\
\hline $\mathrm{CaO}$ & 8.68 & 8.50 & 9.10 & 5.56 & 0.01 & 0.46 & 0.41 & 0.01 & 0.02 & 0.01 \\
\hline $\mathrm{Na}_{2} \mathrm{O}$ & 3.86 & 4.13 & 3.28 & 3.95 & 3.65 & 3.88 & 4.21 & 3.29 & 3.05 & 0.25 \\
\hline $\mathrm{K}_{2} \mathrm{O}$ & 0.76 & 0.98 & 0.91 & 1.64 & 3.93 & 5.32 & 4.51 & 3.91 & 5.36 & 9.21 \\
\hline $\mathrm{P}_{2} \mathrm{O}_{5}$ & 0.23 & 0.23 & 0.79 & 0.98 & 0.04 & 0.03 & 0.02 & 0.03 & 0.01 & 0.02 \\
\hline LOI & 1.20 & 2.60 & 5.23 & 3.39 & 1.61 & 0.80 & 0.67 & 0.67 & 1.70 & 0.83 \\
\hline Total & 99.04 & 99.80 & 99.82 & 100.41 & 99.20 & 99.42 & 98.99 & 100.18 & 97.82 & 100.07 \\
\hline $\mathrm{Ba}$ & 241 & 178 & 542 & 933 & 302 & 127 & 55 & 56 & 54 & 67 \\
\hline $\mathrm{Rb}$ & 22 & 33 & 14 & 35 & 101 & 82 & 144 & 118 & 261 & 446 \\
\hline $\mathrm{Sr}$ & 437 & 496 & 482 & 458 & 20 & 15 & 9 & 10 & 7 & 6 \\
\hline $\mathrm{Nb}$ & 6 & 7 & 14 & 18 & 55 & 35 & 37 & 19 & 81 & 58 \\
\hline $\mathrm{Zr}$ & 140 & 130 & 174 & 259 & 739 & 914 & 491 & 233 & 299 & 437 \\
\hline $\mathrm{Y}$ & 24 & 22 & 41 & 50 & 94 & 55 & 126 & 77 & 84 & 125 \\
\hline $\mathrm{La}$ & 12.5 & 12.3 & 35.5 & 58.0 & 92.9 & 173.0 & 48.9 & 30.4 & 5.6 & 0.8 \\
\hline $\mathrm{Ce}$ & 29.3 & 29.1 & 74.6 & 112.0 & 181.0 & 329.0 & 104 & 60.1 & 20.9 & 6.9 \\
\hline $\operatorname{Pr}$ & - & - & 9.7 & 13.8 & 21.0 & - & 13.3 & 7.98 & - & 0.4 \\
\hline $\mathrm{Nd}$ & 16.0 & 16.0 & 39.0 & 51.9 & 79.9 & 131.0 & 49.9 & 30.8 & 9.9 & 1.9 \\
\hline $\mathrm{Sm}$ & 5.0 & 4.6 & 9.0 & 10.9 & 16.5 & 21.0 & 15.9 & 9.4 & 4.4 & 1.9 \\
\hline $\mathrm{Eu}$ & 1.9 & 1.6 & 2.4 & 2.7 & 0.6 & 1.0 & 0.3 & 0.09 & 0.1 & 0.1 \\
\hline $\mathrm{Gd}$ & - & - & 8.7 & 10.1 & 15.3 & & 17.8 & 10.4 & - & 5.0 \\
\hline $\mathrm{Tb}$ & 0.9 & 0.6 & 1.5 & 1.7 & 3.0 & 2.4 & 3.7 & 2.4 & 2.1 & 2.5 \\
\hline Dy & - & - & 7.5 & 8.7 & 16.9 & - & 22 & 14.3 & - & 21.6 \\
\hline Ho & - & - & 1.5 & 1.7 & 3.5 & - & 4.6 & 2.9 & - & 5.2 \\
\hline $\mathrm{Er}$ & - & - & 3.9 & 4.6 & 9.9 & - & 13.1 & 8.2 & - & 16.0 \\
\hline $\mathrm{Tm}$ & - & - & 0.5 & 0.7 & 1.6 & - & 2 & 1.32 & - & 2.6 \\
\hline $\mathrm{Yb}$ & 2.9 & 2.5 & 3.2 & 4.0 & 9.4 & 5.9 & 11.8 & 7.4 & 9.7 & 15.3 \\
\hline $\mathrm{Lu}$ & 0.4 & 0.3 & 0.5 & 0.6 & 1.4 & 1.1 & 1.7 & 1.05 & 1.4 & 2.2 \\
\hline $\mathrm{U}$ & 0.4 & 0.4 & 0.5 & 1.0 & 6.7 & 1.6 & 3.4 & 2.01 & 2.2 & 3.6 \\
\hline Th & 0.7 & 1.0 & 2.0 & 4.6 & 20.4 & 12.1 & 14.5 & 11.3 & 17.4 & 17.3 \\
\hline $\mathrm{Hf}$ & 3.6 & 3.7 & 4.4 & 6.4 & 18.2 & 16.3 & 17.2 & 8.1 & 11.2 & 11.7 \\
\hline $\mathrm{Ta}$ & - & 0.1 & 1.1 & 1.1 & 29.2 & 1.6 & 2.5 & 1.5 & 5.8 & 4.1 \\
\hline
\end{tabular}

Legend: SH - shoshonitic association (from Lima and Nardi 1998); A - silica, saturated, Na-alkaline association (from Sommer et al 2005): A1 = low-Ti-P basic rocks; A2 = high-Ti-P basic rocks; A3 = high-Ti acidic rocks; A4 $=$ low-Ti acidic rocks; A5 $=$ high-Nb acidic rocks. $(-)$ Not determined. 
erate amounts of HFS elements (Table I, Fig. 3). REE patterns and incompatible trace element signatures show remarkable similarity with intermediate and basic shoshonitic rocks, suggesting their co-geneticity.

Available isotopic data on whole-rock shoshonitic samples in the Lavras do Sul region (Gastal and Lafon 1998) indicate Rb-Sr ages of $608 \pm 54 \mathrm{Ma}$, ${ }^{87} \mathrm{Sr} /{ }^{86} \mathrm{Sr}$ initial ratio about 0.7048 and $\varepsilon \mathrm{Nd}$ values close to -0.2 , which are suggestive of EM1-type lithospheric mantle sources (Nardi and Lima 2000). $\mathrm{Pb}-\mathrm{Pb}$ ages of zircons from monzonitic rocks indicate ages of $601 \pm 5 \mathrm{Ma}$ (Gastal and Lafon 2001) and $\mathrm{U}-\mathrm{Pb}$ isotopic data in zircons point out an age of $592 \pm 5 \mathrm{Ma}$ (Remus et al. 1997) for granitic rocks of this shoshonitic association.

\section{The Silica-Saturated, Sodic Alkaline}

\section{Bimodal MAGMATISM}

The bimodal volcanism is characterized by a basicacidic rock association related to mildly alkaline series, as displayed on TAS (Le Bas et al. 1986) diagram, where the compositional trends are situated close to the limit between subalkaline and silica saturated alkaline fields (Fig. 2a; Table I). Rhyolites of comenditic affinity are predominant in the volcanic sequence. Basic rocks are mostly hawaiites and basalts, whilst mugearitic terms are scarce. The sodic character is indicated by $\left(\mathrm{Na}_{2} \mathrm{O}-2\right)>$ $\mathrm{K}_{2} \mathrm{O}$ values, in spite of their high loss on ignition (LOI) values. Two evolutionary trends with contrasting Ti-P contents were identified and referred to as high- and low-Ti-P basalt-rhyolites (Sommer et al. 2005) (Figs. 2c, 2d). A third compositional group probably represents the last magmatism in the Camaquã Basin, still related to the Brasiliano-PanAfrican post-collisional stage, which is referred to as high-Nb rhyolites (Figs. 2c, 2d, 4b).

The alkaline affinity of this bimodal association is observed in the sliding normalization scheme of Liégeois et al. 1998, where most rocks plot in the field characterized by high SNX-SNY values (Fig. 2b).

The less differentiated rocks present relatively high $\mathrm{FeOt} / \mathrm{MgO}$ ratios usually observed in tholeiitic series, which is corroborated by the behavior of some incompatible elements as $\mathrm{Nb}, \mathrm{Zr}$ and $\mathrm{Y}$, as displayed in Meschede's (1986) diagram (Fig. 4a), and by the $\mathrm{Al}_{2} \mathrm{O}_{3}$ contents, which are similar to those of continental flood basalts of Paraná Basin (Piccirillo et al. 1988).

Trace elements of basic rocks are similar to those of ocean island basalt (OIB), except for the lower $\mathrm{Nb}$, Ta and $\mathrm{P}$ contents and higher $\mathrm{Ba}$ values (Fig. 3c).

A roughly flat normalized REE pattern is characteristic of the low-Ti-P basic rocks, with a slight LREE enrichment relative to HREE, with $\mathrm{La}_{\mathrm{N}} / \mathrm{Yb}_{\mathrm{N}}$ ratios around 3, and absence of Eu anomaly (Fig. 3d). High-Ti-P types are REE enriched when compared to low-Ti-P basalts, have higher LREE/HREE ratios $\left(\mathrm{La}_{\mathrm{N}} / \mathrm{Yb}_{\mathrm{N}}\right.$ close to 10-11) and slight negative-Eu anomalies.

The basic magmatism lies predominantly in the within plate field in diagrams using incompatible elements as observed in figure $4 \mathrm{a}$. They show a transitional pattern when compared to OIB-normalized patterns of within-plate tholeiitic and high-K basaltic magmas (Pearce 1982, Ewart 1982). This behavior is characteristics for basalts of transitional or moderately alkaline affinity, usually related to continental rifts or post-collisional settings, as pointed out by Leat et al. (1986).

The acidic rocks generally have $\mathrm{SiO}_{2}$ values higher than $70 \mathrm{wt} \%$, and are probably crystallized from peralkaline liquids; however, due to loss of alkaline elements during crystallization (Leat et al. 1986) show agpaitic index values close to 1 or even lower. The originally peralkaline affinity of this association is corroborated by $\mathrm{Zr}$ contents generally over $300 \mathrm{ppm}$ (Table I). Volcanic rocks with lower $\mathrm{Zr}$ contents - about 150 ppm - and low agpaitic index are less abundant and show characteristics similar to those of subalkaline metaluminous associations.

Assuming the primary peralkaline character of rhyolitic magmas, their comenditic affinity is confirmed on the $\mathrm{FeO}_{\mathrm{t}} \times \mathrm{Al}_{2} \mathrm{O}_{3}$ diagram (MacDon- 

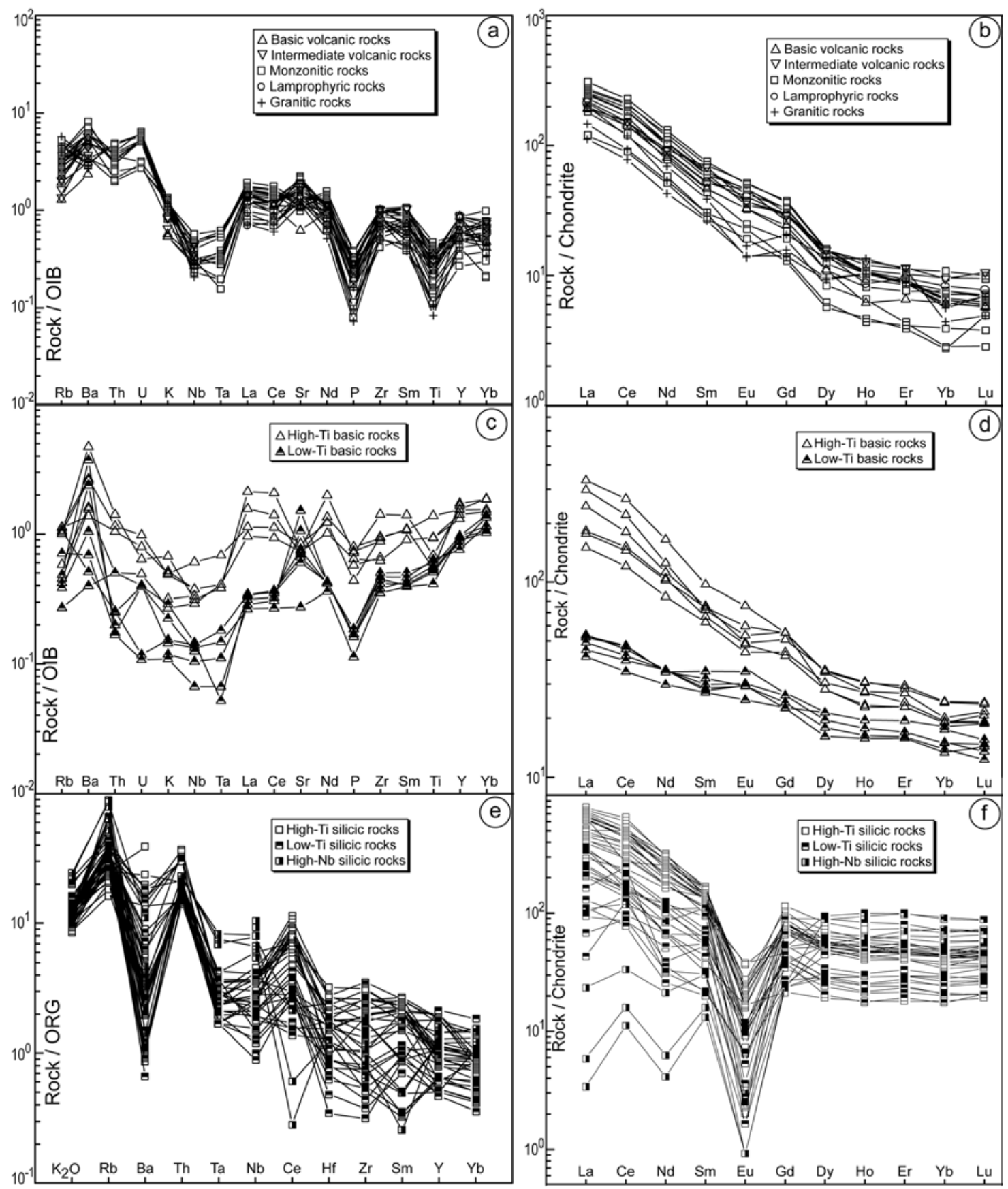

Fig. 3 - (a) Tectonic environment discrimination $\mathrm{Zr} / 4-\mathrm{Y}-\mathrm{Nb} / 2$ diagram (Meschede 1986) for basic rocks of the Na-alkaline association; (b) $\mathrm{FeO}_{t}$ vs. $\mathrm{TiO}_{2}$ and (c) $\mathrm{Al}_{2} \mathrm{O}_{3}$ vs. $\mathrm{FeO}_{t}$ (MacDonald 1974) diagrams for acidic rocks of the Na-alkaline association; (d) tectonic environment discrimination $\mathrm{Y}$ vs. Nb diagram (Pearce et al. 1984) for acidic rock of the Na-alkaline association. Legend: Syn-Colg = syn-collision granites, VAG = volcanic arc granites, $\mathrm{WPG}=$ within plate granites, $\mathrm{ORG}=$ ocean ridge granites; (e) $\mathrm{Zr}$ vs. $\mathrm{Nb}$ diagram (modified from Leat et al. 1986) plotting for acidic rock of the Na-alkaline association. 
ald 1974, Le Maitre 2002) (Fig. 4c). The high-Nb comendites show more peralkaline compositions than high and low-Ti acidic rocks, with higher Ta contents, which are commonly referred to in pantelleritic associations (Hildreth 1981). The acidic rocks have $\mathrm{FeOt} /(\mathrm{FeOt}+\mathrm{MgO})$ ratios dominantly higher than 0.9, which are typical of rhyolites associated to alkaline series (Ewart 1979, 1982).

Trace element patterns of rhyolites normalized against the ORG values (Pearce et al. 1984.) are displayed in the figure $3 \mathrm{e}$, where rhyolites show patterns similar to those found in within plate granitic rocks, particularly of attenuated continental lithosphere. Their high $\mathrm{Ce} / \mathrm{Nb}$ ratios are like those found in post-orogenic magmatic associations, such as Snowdon Rhyolites (Leat et al. 1986). The lower $\mathrm{Ce}$ and $\mathrm{Sm}$ and, higher $\mathrm{Rb}$ and Ta contents, together with the lower $\mathrm{Ce} / \mathrm{Nb}$ ratios of high- $\mathrm{Nb}$ rhyolites suggest that this magmatism is related to sources with less influence of subduction-related metasomatism, like the Naivasha Rhyolites, Kenya (MacDonald et al. 1987).

Chondrite-normalized REE patterns (Fig. 3f) show a slight enrichment of REE in the high-Ti rhyolites, particularly for LREE, with a $\mathrm{La}_{\mathrm{N}} / \mathrm{Yb}_{\mathrm{N}}$ ratio about 10-12. The high-Nb acidic rocks present $\mathrm{La}_{\mathrm{N}} / \mathrm{Yb}_{\mathrm{N}}$ ratio close to 1 or 2, larger negative Eu anomalies and a strong LREE depletion in the most differentiated liquids, which probably reflect the presence of LREE-rich minerals, like allanite, among the fractionated phases or a different source.

In the $\mathrm{Y} \times \mathrm{Nb}$ diagram (Fig. $4 \mathrm{~d}$ ), the sodic alkaline rocks plot mainly in the field of postcollisional magmatism, whilst high-Nb rocks occupy the field closer to that of within-plate associations. A similar behavior is observed in the $\mathrm{Zr} \times \mathrm{Nb}$ diagram (Fig. 4e) where the rhyolitic rocks in general present $\mathrm{Zr} / \mathrm{Nb}$ ratios $>10$, which indicate that this magmatism is related to sources modified by subduction, such as those of post-collisional settings. This kind of magmatic association has been described in provinces such as Snowdonia, Avoca and Parys Mountain, within the Southern British Caledonides (Leat et al. 1986). The high-Nb rocks show $\mathrm{Zr} / \mathrm{Nb}$ ratios $<10$, which is usually related to anorogenic settings as that of Naivasha volcanic association, Kenya (MacDonald and Bailey 1973).

Isotopic data obtained from bimodal volcanism supplied ages varying from 549 to $602 \mathrm{Ma}$. U$\mathrm{Pb}$ ages within this range were obtained in zircons from different volcanic types (Siga Jr et al. 1995, Cordani et al. 1999, Chemale Jr 2000, Sommer et al. 2005).

\section{FINAL CONSIDERATIONS}

The Neoproterozoic shoshonitic and mildly alkaline bimodal volcanism of Southernmost Brazil is represented by rock assemblages associated to volcanosedimentary successions, deposited in strike-slip basins formed at the post-collisional stages of the Brasilian/Pan-African orogenic cycle. The geotectonic setting during this period in southern Brazil can be envisaged as resultant from the collisional system associated with the amalgamation of Rio de La Plata, São Francisco, Congo, Kalahari and Paraná cratons, as suggested by Brito Neves and Cordani (1991), leading to the formation of Gondwana supercontinent. The influence of collisions related to the Pampean Orogeny (Rapela et al. 1998) in the development of Cambrian shear belts in southern Brazil can not be discarded, particularly for late-transcurrent events such as that related to the Caçapava Granite Complex intrusion with age of $550 \mathrm{Ma}$ (Nardi and Bitencourt 1989). This long period of transcurrent tectonics with associated strike-slip basin formation and associated magmatism, related to the consolidation of Gondwana supercontinent, explains the wide time interval of Brasiliano post-collisional magmatism in southern Brazil (650-540 Ma).

The best-preserved volcano-sedimentary associations occur in the Camaquã and Campo Alegre Basins, respectively in the Sul-rio-grandense and Catarinense Shields and are outside the main shear belts or overlying the unaffected basement areas. These basins are characterized by alternation of volcanic cycles and siliciclastic sedimentation developed dominantly on a continental setting under sub- 


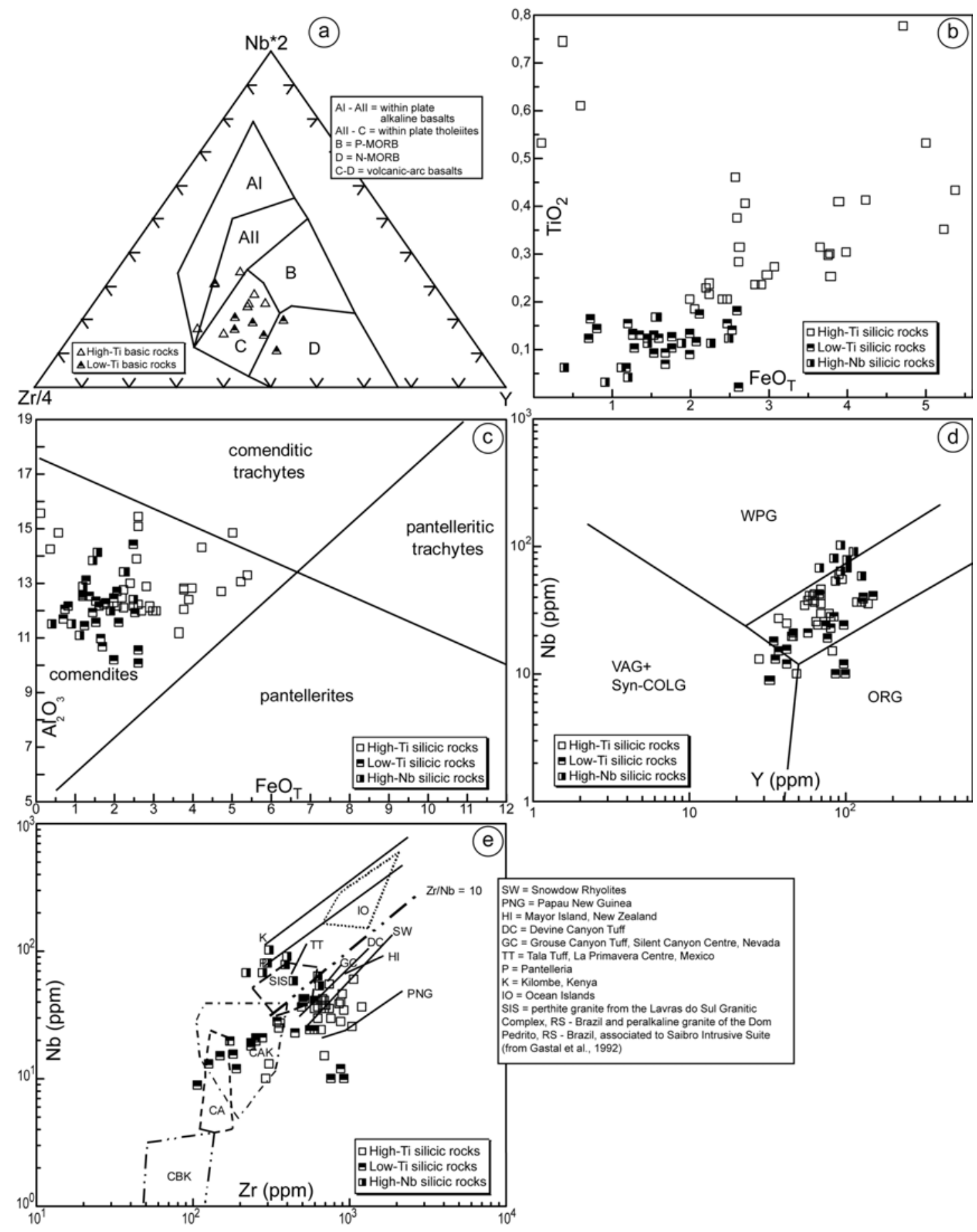

Fig. 4 - (a) Tectonic environment discrimination $\mathrm{Zr} / 4-\mathrm{Y}-\mathrm{Nb} / 2$ diagram (Meschede 1986) for basic rocks of the Na-alkaline association; (b) $\mathrm{FeO}_{t}$ vs. $\mathrm{TiO}_{2}$ and (c) $\mathrm{Al}_{2} \mathrm{O}_{3}$ vs. $\mathrm{FeO}_{t}$ (MacDonald 1974) diagrams for acidic rocks of the Na-alkaline association; (d) tectonic environment discrimination Y vs. Nb diagram (Pearce et al. 1984) for acidic rock of the Na-alkaline association. Legend: Syn-Colg = syn-collision granites, $\mathrm{VAG}=$ volcanic arc granites, $\mathrm{WPG}=$ within plate granites, $\mathrm{ORG}=$ ocean ridge granites; (e) $\mathrm{Zr}$ vs. $\mathrm{Nb}$ diagram (modified from Leat et al. 1986) plotting for acidic rock of the Na-alkaline association. 
aerial conditions (Paim et al. 2000, Wildner et al. 2002), associated to coeval plutonism that evolved from high-K tholeiitic and calc-alkaline to shoshonitic and ended with a silica-saturated sodic alkaline magmatism. Ultrapotassic lamprophyres and silicasaturated syenitic rocks coeval with the shoshonitic magmatism were described by Stabel et al. (2001) and Plá Cid et al. (2003).

The shoshonitic component is represented by Hilário Volcanism in the Camaquã Basin, while the alkaline signature is typical of the younger Acampamento Velho and Campo Alegre volcanisms, respectively in the Camaquã and Campo Alegre basins.

The available isotopic data indicate that shoshonitic Hilário volcanism occurred between 608 Ma and $592 \pm 5$ Ma and the bimodal mildly alkaline magmatism of the Acampamento Velho and Campo Alegre volcanism between $602 \mathrm{Ma}$ and $549 \mathrm{Ma}$. These ages are coherent with those found in the coeval extensional granitic plutonism, indicating that evolution of shoshonitic and mildly alkaline bimodal magmatism was developed during at least $60 \mathrm{Ma}$.

Bimodal volcanism was carried out over Paleoproterozoic granulitic complexes or over metamorphic terrains with juvenile protoliths and in spite of these basement differences, volcanic episodes and facies architecture in the studied basins are similar, with a predominance of acidic over basic magmatism and an less expressive occurrence of intermediate rocks, mainly trachytic lavas and small syenitic plutons (Wildner et al. 2002, Waichel et al. 2000). The bimodal magmatism according to mineralogical, trace and major element data belongs to the silica-saturated sodic alkaline series and shows high $\mathrm{FeO}_{\mathrm{T}} / \mathrm{MgO}$ ratios comparable to those of continental flood basalts. Two magmatic sequences were identified and referred to as high-Ti-P basalts-rhyolites and low-Ti-P basalts-rhyolites.

The compositional differences observed in the high- and low-Ti-P groups are attributed to different melt fractions from a dominantly lithospheric mantle, previously affected by subduction (Wildner et al. 2002, Sommer et al. 2005).
The volcanic cycles investigated in Neoproterozoic basins of southernmost Brazil represent part of evolutionary sequences that are typical of postcollisional magmatism. This magmatism marks the final stages of the post-collisional period and the exhausting of mantle reservoirs hydrated and metasomatized by processes related to a previous subduction. The latest volcanism, characterized by the high-Nb rhyolites, probably represents an asthenospheric contribution and can be interpreted as result of slab break-off and asthenospheric upwelling as proposed by Atherton and Ghani (2002).

The post-collisional magmatism evolution from high-K subalkaline to shoshonitic and eventually to sodic mildly alkaline observed in southernmost Brazil (Nardi and Bonin 1991, Bitencourt and Nardi 1993, 2000, Gastal and Lafon 1998, 2001, Wildner et al. 2002, Waichel et al. 2000, Sommer et al. 2005, Nardi and Lima 2000) is referred elsewhere as in Snowdonia and Parys Mountain associations in the British Caledonides (Leat et al. 1986), Devine Canyon Tuff - USA (Greene 1973) and Miocene post-collisional volcanism of the Eastern Rif in Morocco (El Bakkali et al. 1998). This evolution is characterized by development of shear belts associated to predominantly granitic magmatism and strike-slip basins where a typical and voluminous volcanism and associated sedimentation was developed and preserved, as envisaged by Bonin (2004) for the evolution of the Alpine Belt since the end of Variscan orogeny in Europe.

The post-collisional magmatism in southern Brazil shows some particular features that should be emphasized: (i) the last post-collisional magmatic events are sodic instead of potassic or ultrapotassic and (ii) the early magmatic stages of mafic magmatism are dominantly high-K tholeiitic instead of calc-alkaline (ii) the ultrapotassic lamprophyresyenitic magmatism (611 Ma; Plá Cid et al. 2003) is approximately coeval with the shoshonitic one. The compositional variation and evolution of postcollisional magmatism in southern Brazil is interpreted as result mainly of melting of a heterogeneous mantle source, which includes garnet-phlogopite- 
bearing peridotites, veined-peridotites with abundant hydrated phases, such as amphibole, apatite and phlogopite, and eventually with the addition of an asthenospheric component. Crustal melts are significative within the major post-collision shear belts where peraluminous acidic rocks have been described by several authors (e.g. Bitencourt and Nardi 1993). The subduction-related metasomatic character of post-collisional magmatism mantle sources in southern Brazil is put in evidence by $\mathrm{Nb}$ negative anomalies and isotope features typical of EM1 sources.

\section{ACKNOWLEDGMENTS}

This work was financially supported by Fundação de Amparo à Pesquisa do Estado do Rio Grande do Sul (FAPERGS - 03/0686.2 and BIC 03/50288.0) and Conselho Nacional de Desenvolvimento Científico e Tecnológico/Programa de Apoio a Núcleos de Excelência (CNPq/PRONEX - 4700181/01-5 and 471584/2001-0). The authors are grateful to Centro de Estudos em Petrologia e Geoquímica (CPGq) of the Universidade Federal do Rio Grande do Sul (UFRGS) and Companhia de Pesquisa de Recursos Minerais (CPRM - SUREG PA) by logistical support.

\section{RESUMO}

O vulcanismo neoproterozóico de afinidades shoshonítica e alcalina sódica saturada em sílica, do sul do Brasil é representado por uma sucessão de rochas vulcânicas, associadas com seqüências sedimentares que foram depositadas em bacias do tipo strike-slip, formadas nos estágios pós-colisionais do ciclo orogênico Brasiliano/Panafricano. As associações vulcano-sedimentares mais bem representadas ocorrem nas bacias Camaquã e Campo Alegre, respectivamente nos escudos Sul-rio-grandense e Catarinense e situam-se fora das principais zonas de cisalhamento ou sobrepondo áreas não afetadas do embasamento. Estas bacias são caracterizadas pela alternância de ciclos vulcânicos e sedimentação siliciclástica, desenvolvidos dominantemente sob condições subaéreas em ambientes continentais. O vulcanismo é associado com plutonismo, cujo magmatismo evoluiu de afinidades toleítica e cálcio-alcalina alto-K, para shoshonítica e, finalmente, alcalina sódica e saturada em sílica, durante, pelo menos, $60 \mathrm{Ma}$. A variação composicional e a evolução do magmatismo pós-colisional do sul do Brasil são interpretadas como sendo, principalmente, resultado da fusão de uma fonte mantélica heterogênea, que inclui peridotitos ricos em granada e flogopita, peridotitos venulados com abundância em fases hidratadas, tais como anfibólio, apatita e flogopita e, eventualmente, contando com a adição de um componente astenosférico. A característica metassomática relacionada a subducção das fontes mantélicas deste magmatismo pós-colisional é evidenciada pelas anomalias negativas de $\mathrm{Nb}$ e características isotópicas, típicas de fontes do tipo EM1.

Palavras-chave: Pós-colisional, neoproterozóico, vulcanismo, shoshonito, alcalino sódico.

\section{REFERENCES}

Almeida DPM, Zerfass H, BASEI MA AND Mello KS. 1997. Caracterização geoquímica da sucessão vulcânica dos Cerros do Bugio e Perau (Bacia do Camaquã, sub-Bacia Santa Bárbara), Caçapava do Sul, RS. Congresso Brasileiro de Geoquímica 6, Salvador, BA, p. 698-702.

Almeida DPM, Zerfass H, Basei MA, Petry K And Gomes CH. 2002. The Acampamento Velho Formation, a Lower Cambrian Bimodal Volcanic Package: Geochemical and Stratigraphic Studies from the Cerro do Bugio, Perau and Serra de Santa Bárbara (Caçapava do Sul, Rio Grande do Sul, RS - Brazil). Gondwana Res 5: 721-733.

Almeida FFM, Hasui Y AND BRito Neves BB. 1981. Brazilian structural provinces: an introduction. Earth Sci Rev 17: 1-29.

ATHERTON MP AND GHANi AA. 2002. Slab break-off: a model for Caledonian, late granite syn-collisional magmatism in the orthotectonic (metamorphic) zone of Scotland and Donegal, Ireland. Lithos 62(3-4): $65-85$.

BASEi MAS, Siga JR O, Machiavelli A ANd MANCINI F. 1992. Evolução tectônica dos terrenos entre os cinturões Ribeira e Dom Feliciano (PR-SC). Rev Bras Geoc 22: 216-221. 
BITENCOURT MF AND NARDI LVS. 1993. Late to Postcollisional Brasiliano granitic magmatism in southernmost Brazil. An Acad Bras Cienc 65: 3-16.

Bitencourt MF AND NARdi LVS. 2000. Tectonic setting and sources of magmatism related to the Southern Brazilian Shear Belt. Rev Bras Geoc 30: $186-189$.

BONIN B. 2004. Do coeval mafic and felsic magmas in posto-collisional to within-plate regimes necessarily imply two contrasting, mantle and crustal, sources? A review. Lithos 78: 1-24.

Brito Neves BB And Cordani UG. 1991. Tectonic evolution of South America during Late Proterozoic. Precamb Res 53: 23-40.

Chemale JR F. 2000. Evolução Geológica do Escudo Sul-rio-grandense. In: DE Ros LF AND Holz M (Eds), Geologia do Rio Grande do Sul. Porto Alegre: CIGO/UFRGS, p. 13-52.

Cordani UG, BASEi MAS, Siga JR O AND NutMAN A. 1999. Idades U-Pb (SHRIMP) de rochas vulcânicas das Bacias de Campo Alegre, Itajaí e Castro (SC e PR). An Acad Bras Cienc 71: 835

Daitx EC And CARvalho MAS. 1980. Projeto geoquímica da área de Guaratubinha-Pien, Brasil. São Paulo, DNPM/CPRM, 184 p.

DAVIES J AND HAWKESWORTH CJ. 1994. Early calcalkaline magmatism in the Mogollon-Datil Volcanic Field, New Mexico, USA. J Geol Soc London 151: 825-843.

EBERT H. 1971. O Grupo Guaratubinha no norte do estado de Santa Catarina. Congresso Brasileiro de Geologia 25, São Paulo, SP, SBG 1: 147-165.

El Bakkali S, Gourgaud A, Bourdier JL, BelLON H AND Gundogdu N. 1998. Post-collision neogene volcanism of the Eastern Rif (Morocco): magmatic evolution through time. Lithos 45: 523543.

EWART A. 1979. A review of the mineralogy and chemistry of Tertiary-Recent dacitic, latitic, rhyolitic and related salic volcanic rocks. In: BAKER F (Ed), Trondhjemites, dacites and related rocks, The Hague: Elsevier, p. 113-121.

EWART A. 1982. The Mineralogy and Petrology of Tertiary-Recent Orogenic Volcanic Rocks: with special reference to the andesitic-basaltic compositional range. In: THORPE RS (Ed), Andesites, New York, J Wiley \& Sons, p. 25-87.

GASTAL MCP AND LAFON JM. 1998. Gênese e evolução dos granitóides metaluminosos de afinidade alcalina da porção oeste do escudo sul-rio-grandense: geoquímica e isótopos de $\mathrm{Rb}-\mathrm{Sr}$ e $\mathrm{Pb}-\mathrm{Pb}$. Rev Bras Geoc 28: 11-28.

GASTAL MCP AND LAFON JM. 2001. Novas idades $207 \mathrm{~Pb} / 206 \mathrm{~Pb}$ e geoquímica isotópica $\mathrm{Nd}-\mathrm{Sr}$ para granitóides shoshoníticos e alcalinos das regiões de Lavras do Sul e Taquarembó, RS. VIII Congresso Brasileiro de Geoquímica, p. 21-26.

GREENE RC. 1973. Petrology of the welded tuff of Devine Canyon, Southeastern Oregon. US Geol Surv Prof Paper 797: 26.

Gresse PG, Chemale Jr F, Silva LC, Walraven F AND HARTMANN LA. 1996. Late to post orogenic basins of the Pan-African-Brasiliano collision orogen in southern Africa and southern Brazil. Basin Res 8: $157-171$.

HILDRETH W. 1981. Gradients in acidic magma chambers: implications for lithospheric magmatism. J Geophys Res 86: 10153-10192.

Kelemen PB, Shimizu N And DunN T. 1993. Relative depletion of niobium in some arc magmas and the continental crust: partitioning of $\mathrm{K}, \mathrm{Nb}, \mathrm{La}$ and Ce during melt/rock reaction in the upper mantle. Earth Planet Sci Lett 120: 111-134.

Le Bas MJ, Le Maitre RW, Streckeisen A And ZANETTIN B. 1986. A classification of volcanic rocks based on the total alcalis-silica diagram. J Petrol 27: 745-750.

Le Maitre RW. 2002. Igneous rocks: a classification and glossary of terms. In: RECOMMENDATIONS OF THE INTERNATIONAL UNION OF GEOLOGICAL SCIENCES SubCOMMISSION ON THE SystemATIC OF IgNeOus Rocks. Cambridge: Cambridge University Press, $252 \mathrm{p}$.

LEAT PT, JACKSON SE, ThORPE RS AND STILLMAN CJ. 1986. Geochemistry of bimodal basalt - subalkaline/peralkaline rhyolite provinces within the Southern British Caledonides. J Geol Soc London 143: 259-273.

LIÉGEOIS JP. 1998. Preface - Some words on postcollisional magmatism. Lithos 45: 15-17. 
LiÉGEois JP, NAVEZ J, HeRtogen J AND Black R. 1998. Contrasting origin of post-collisional high-K calc-alkaline and shoshonitic versus alkaline and peralkaline granitoids. The use of sliding normalization. Lithos 45: 1-28.

LIMA EF AND NARDi LVS. 1991. Os Lamprófiros Espessartíticos da Associação Shoshonítica de Lavras do Sul, RS. Geochim Bras 5: 117-131.

Lima EF AND NARdi LVS. 1998. The Lavras do Sul Shoshonitic Association: implications for the origin and evolution of Neoproterozoic shoshonitic magmatism in the southernmost Brazil. J S Am Earth Sci 11: 67-77.

MacDonald R. 1974. Nomenclature and Petrochemistry of the Peralkaline Oversaturated Extrusive Rocks. Bull Volcan 38: 498-516.

MacDonald R And BAILEy DK. 1973. The chemistry of the peralkaline oversaturated obsidians. US Geol Surv Prof Paper 440: 1-37.

MacDonald R, Davies GR, Bliss CM, Leat PT, BAILEY DK AND SMITH RL. 1987. Geochemistry of High-silica Peralkaline Rhyolites, Naivasha, Kenya Rift Valley. J Petrol 28: 979-1008.

Meschede M. 1986. A method of discriminating between different types of Mid-Ocean ridge basalts and continental tholeiites with the $\mathrm{Nb}-\mathrm{Zr}-\mathrm{Y}$ diagram. Chem Geol 56 (3/4): 207-218.

NARDi LVS AND BITENCOURT MFAS. 1989. Geologia, petrologia e geoquimica do Complexo Granítico de Caçapava do Sul, RS. Rev Bras Geoc 19: 153-169.

NARdi LVS AND Bonin B. 1991. Post-orogenic and non-orogenic alkaline granite associations: the Saibro intrusive suite, southern Brazil - A case study. Chem Geol 92: 197-212.

NARdi LVS AND LIMA EF. 2000. O magmatismo Shoshonítico e Alcalino da Bacia do Camaquã - RS. In: De Ros LF And Holz M (Eds), Geologia do Rio Grande do Sul, Porto Alegre: CIGO/UFRGS, p. 119-131.

Paim PSG, Chemale JR F And Lopes RC. 2000. A Bacia do Camaquã. In: DE Ros LF AND Holz M (Eds), Geologia do Rio Grande do Sul, Porto Alegre: CIGO/UFRGS, p. 231-374.

PeArCE JA. 1982. Trace elements characteristics of lavas from destructive plate bondaries. In: THORPE
RS (Ed), Andesites: Orogenic Andesites and Related Rocks, New York, J Wiley \& Sons, p. 525-546.

PEARCE JA. 1983. Role of the sub-continental lithophere in magma genesis at active continental margins. In: HAWkesworth CJ AND NorRy MJ (Eds), Continental basalts and mantle xenoliths, Cheshire, UK: Shiva Publ, p. 230-256.

Pearce JA, Harris NBW and Tindle AG. 1984. Trace element discrimination diagrams for the tectonic interpretation of granitic rocks. J Petrol 25: 956-983.

PICCIRILlo EM ET AL. 1988. Petrochemistry of continental flood basalt-rhyolite suites and related intrusives from the Paraná Basin (Brazil). In: PICCIRILlo EM AND Melfi AJ (Eds), The Mesozoic Flood Volcanism of the Paraná Basin: Petrogenetic and Geophysical Aspects, São Paulo: Instituto Astronômico e Geofísico, Universidade de São Paulo, SP, Brazil, p. 107-156.

Plá Cid J, Nardi lVS, Stabel LZ, Conceição RV AND BALZARETTI NM. 2003. High-pressure minerals in mafic microgranular enclaves: evidences for co-mingling between lamprophyric and syenitic magmas at mantle conditions. Contrib Mineral Petrol 145: 444-459

Rapela CW, Pankhurst RJ, Casquet C, Baldo E, SaAvedra J and Galindo C. 1998. Early evolution of the proto-Andean margin of South America. Geology 26: 707-710.

Remus MVD, MCNAughton NJ, HaRTMANN LA AND FLETCHER IR. 1997. Zircon SHRIMP dating and $\mathrm{Nd}$ isotope data of granitoids of the São Gabriel Block, southern Brazil: evidence of an Archaean/Paleoproterozoic basement. In: INTERNATIONAL SYMPOSIUM ON GRANITES AND ASSOCiated Mineralization 2, Salvador, Extended Abstracts 1: 217-272.

Siga JR O, BASEI MAS ANd Citrone SB. 1995. Contribuição ao estudo das bacias de Campo Alegre e Guaratubinha, SC-PR. Simpósio Sul-Brasileiro de Geologia 6, Porto Alegre, RS, Brasil, p. 207-209.

Sommer CA, Lima EF AND NARdi LVS. 1999. Evolução do vulcanismo alcalino na porção sul do Platô do Taquarembó, Dom Pedrito - RS. Rev Bras Geoc 29: 245-254.

Sommer CA, Lima EF, NArdi LVS, Figueiredo 
AMG AND PIEROSAN R. 2005. Potassic and Lowand High-Ti Mildly Alkaline Volcanism in the Neoproterozoic Ramada Plateau, Southernmost Brazil. J S Am Earth Sci 18: 237-254.

Stabel LZ, NARdi LVS AND Plá CID J. 2001. Química mineral e evolução petrologica do Sienito Piquiri: magmatismo shoshonítico, neoproterozóico, pós-colisional no sul do Brasil. Rev Bras Geoc 31: 211-222.

STRONG DF AND TAYLOR RP. 1984. Magmatic-subsolidus and oxidation trends in compositions of amphiboles from silica-saturated peralkaline igneous rocks. Mineral Petr Mitt 32: 211-222.

SutherLAND DS. 1975. Petrography and Mineralogy of the Peralkaline Silicic Rocks. Bull Volcanol 38: 517-547.
WAICHEL BL, LIMA EF, NARDI LVS AND SOMMER CA. 2000. The Alkaline Post-Collisional Volcanism of Campo Alegre Basin in Southern Brazil: Petrogenetic Aspects. Rev Bras Geoc 30: 393-396.

WedePOHL KH. 1995. The composition of the continental crust. Geochim Cosmochim Acta 95: 12171232 .

Wildner W, Lima EF, NARdi LVS AND SOMMER CA. 2002. Volcanic cycles and setting in the Neoproterozoic III to Ordovician Camaquã Basin succession in southern Brazil: characteristics of post-collisional magmatism. J Volcanol Geoth Res 118: 261-283. 